\title{
Correlation Between Nutritional Status and Serum Vitamin D Level in Children
}

\author{
Sihombing L B ${ }^{a^{*}}$, Sembiring T, Sugih Arto K, Pratita W \\ adr_leosihombing@yahoo.com \\ Departemen Ilmu Kesehatan Anak Fakultas Kedokteran \\ Universitas Sumatera Utara, Medan-Indonesia
}

\begin{abstract}
Introduction : Vitamin D has various essential roles in the physiological functions of the body. The incidence of vitamin D insufficiency in Indonesia is $49.3 \%$. Malnourished children tend low serum vitamin D levels due to impaired synthesis. Children with poor nutrition have less subcutaneous tissue and are more often at home so they are rarely exposed to sunlight.. Aim : To assess the correlation between nutritional status and serum vitamin D level in children.

Methods: This cross-sectional study was conducted in outpatient and inpatient pediatric services at H. Adam Malik Hospital from March to October 2020. Sample characteristics were obtained through interviews with parents and the results of anthropometric measurements and vitamin D levels of the study sample.

Results: Of the 60 children consisting of 30 children with well-nourished and 30 malnourished, the average serum vitamin D level was $19.38 \mathrm{ng} / \mathrm{mL}$, with normal $35 \%$, insufficiency $43.3 \%$, and deficiency $21.7 \%$. The Chi-Square test showed a significant relationship between nutritional status and vitamin D levels $(p=0.02)$ and a prevalence ratio of 1.6 with $95 \%$ CI. Conclusion: Positive association between nutritional status and serum vitamin D level in children was found in this study.
\end{abstract}

Key Words: vitamin D; well-nourished; malnourished

\section{Introduction}

Nutritional problems in children are caused by inadequate or excessive food intake to meet the body's needs. ${ }^{1}$ Assessment of nutritional status aims to determine the prevalence of nutritional status at a certain time or to determine the development of the prevalence of nutritional status in the population from time to time. ${ }^{2}$

Vitamin D is a pro-hormone that has various substantial roles in the physiological functions of the body. ${ }^{3}$ Vitamin D status in the body is determined based on the level of $25(\mathrm{OH}) \mathrm{D}$, which has a fairly long halflife of 2-3 weeks. ${ }^{4}$

In a study conducted in four countries, Indonesia was ranked fourth, with an average vitamin D serum level of only $52.7 \mathrm{nmol} / 1(16.5 \mathrm{ng} / \mathrm{mL}) .{ }^{5}$ Research in Pakistan has shown that giving high doses of vitamin $\mathrm{D}$ to severely malnourished children responds to weight gain and muscle mass. ${ }^{6,7}$ Children with poor nutrition have little subcutaneous tissue so that the synthesis of vitamin D in the skin is disrupted, where vitamin D will not be converted into active metabolites. ${ }^{8}$ Vitamin D synthesis disorders are also found in malnourished children because they usually suffer from chronic diseases that cause children to be inactive and more often at home, so they are rarely exposed to sunlight. This causes a tendency to decrease serum vitamin D levels due to impaired synthesis. ${ }^{9}$

Research on the relationship between serum vitamin D levels in malnourished children in Indonesia has not been conducted. In a state of malnutrition, there is a decrease in the concentration of vitamin D receptors. The sensitivity of vitamin D binding protein (DBP) to protein and energy intake could form a new mechanism that could explain the relationship between malnutrition and bone development and metabolic diseases. ${ }^{10,11}$ Vitamin D receptors transport $95 \%-99 \%$ of $25(\mathrm{OH}) \mathrm{D}$ in the body. The main component of DBP is a protein $(\alpha$ globulin). Albumin and lipoproteins carry a small proportion of vitamin D metabolites, although they are more widely circulated in the blood circulation than DBP. Children who suffer from malnutrition will experience a decrease in the concentration of DBP in the blood circulation. ${ }^{11}$ However, DBP levels were not affected by insufficient calcium intake. There was no effect of food intake on DBP's affinity for its main ligand, namely $25(\mathrm{OH}) \mathrm{D}$. $^{10,11}$

Imawari reported that protein concentration decreased in malnourished children so that vitamin $\mathrm{D}$ would decrease due to a decrease in vitamin D binding protein. However, the results showed that there was no change in vitamin D levels even though there was a decrease in the amount of serum albumin. Because the research subjects are children who live in poverty are more often exposed to the sun even though they get a small intake 
of vitamin D sources. In addition, children with malnutrition generally become less active like normal children and are less exposed to sunlight, which results in low vitamin D levels. ${ }^{12,13}$

Malnourished children are more susceptible to infection, which can be associated with low vitamin D levels. Vitamin D deficiency is responsible for changes in the immune response leading to an increased risk of infection. Vitamin D enhances innate immunity against various infections, especially tuberculosis, influenza, and viral upper respiratory tract diseases. A case-control study of the relationship between vitamin D status and tuberculosis showed that the mean levels of pulmonary and extrapulmonary tuberculosis patients $(10.7 \mathrm{ng} / \mathrm{mL})$ were significantly different from those of controls $(19,5 \mathrm{ng} / \mathrm{mL}) .{ }^{14}$

Children with malnutrition have little subcutaneous tissue that the synthesis of vitamin $\mathrm{D}$ in the skin is impaired. Vitamin D will not be converted into active metabolites. In addition to impaired vitamin D synthesis, malnourished children also suffer from chronic diseases and are rarely exposed to sunlight. They tend to have lower serum vitamin D levels. ${ }^{11,14}$ Research by Walli Nahida et al showed that $30.6 \%$ of the sample from children under 5 years of age with poor nutritional status in tertiary health care in Tanzania was in the category of vitamin D deficiency. ${ }^{15}$

\section{Methods}

This is a cross-sectional study that assessed the correlation between nutritional status and serum vitamin D levels in children. This study was conducted in outpatient and inpatient services at H. Adam Malik Hospital Medan. The study was carried out from March 2020 to October 2020, with a sample size of 30 people in each group. This research was approved by the Research Ethics Committee of Haji Adam Malik Hospital, Faculty of Medicine, Universitas Sumatera Utara.

\section{Data Analysis}

Data processing and analysis is performed with statistical software SPSS version 20.0. To see the relationship between independent variable and dependent variable, a bivariate test was performed using the ChiSquare test with Fischer's Exact test as the alternative.

\section{Results}

Of the 60 children, there are 30 children well-nourished and 30 malnourished. There were 32 male subjects $(53.3 \%)$ and 28 female subjects $(46.7 \%)$. The percentage of male subjects is $6.6 \%$ more than females. The age of the research subjects had a median of 10.15 years, with the oldest is 17 years 9 months old and the youngest is 5 years 1 month old.

The mean serum vitamin D level was $19.38 \mathrm{ng} / \mathrm{mL}$, where the vitamin D level status was $35 \%$ in the normal category, $43.3 \%$ in the insufficiency category, and $21.7 \%$ in the deficiency category. Exposure to sunlight for more than 15 minutes was found in $40 \%$ of subjects, duration of sun exposure was less than 15 minutes in $60 \%$ of subjects.

The most common diagnoses in the research subjects were fever as many as 9 people (15\%), followed by respiratory disorders and surgical cases each as many as 8 people $(13,3 \%)$. Other diagnoses found included neurological disorders, urinary tract disorders, cardiovascular disorders in 7 people $(11.7 \%)$, trauma and gastroenteritis in 5 people $(8.3 \%)$, and other cases in 4 people $(4 \%)$.

The subject characteristics can be seen thoroughly in Table 1.

Tabel 1. Karakteristik subjek penelitian $(\mathrm{N}=60)$

\begin{tabular}{ll}
\hline Characteristic & $\mathbf{N}=\mathbf{6 0}$ \\
\hline Age (median) & $10,15(5,1-17,9)$ \\
Gender & 32 \\
$\quad>$ Male & 28 \\
$\quad>$ Female & 19,38 \\
Vitamin D level mean $(\mathrm{ng} / \mathrm{mL})$ & \\
Serum Vitamin D Status & 21 \\
$\quad>$ Normal & 26 \\
$>$ Insufficiency & 13 \\
$>$ Deficiency & \\
Education & 19 \\
$>$ Not going to school & 25 \\
$>$ Elementary School & 10 \\
$>$ Middle School & 6
\end{tabular}


Sun exposure duration

$><15$ minutes

$>15$ minutes

Diagnosis

$>$ Cardiovascular disorder

- Post Trauma

Respiratory disorders

Fever

Gastroenteritis

Surgery cases

Neurological disorders

Based on Figure 1 below, we can also see how the average serum levels of vitamin D in each category are for each group of undernourished and well-nourished. The mean levels of vitamin $\mathrm{D}$ in the undernourished group: deficiency $13.22 \pm 0.91 \mathrm{ng} / \mathrm{mL}$, insufficiency $17.57 \pm 1.41 \mathrm{ng} / \mathrm{mL}$, and normal $22.85 \pm 3.49 \mathrm{ng} / \mathrm{mL}$. Average levels of vitamin D in the well-nourished group: deficiency $13.83 \pm 1.51 \mathrm{ng} / \mathrm{mL}$, insufficiency $18.39 \pm 1.24 \mathrm{ng} / \mathrm{mL}$, and normal $26.41 \pm 6.59 \mathrm{ng} / \mathrm{mL}$.

Figure 1. Mean level of vitamin D in each group

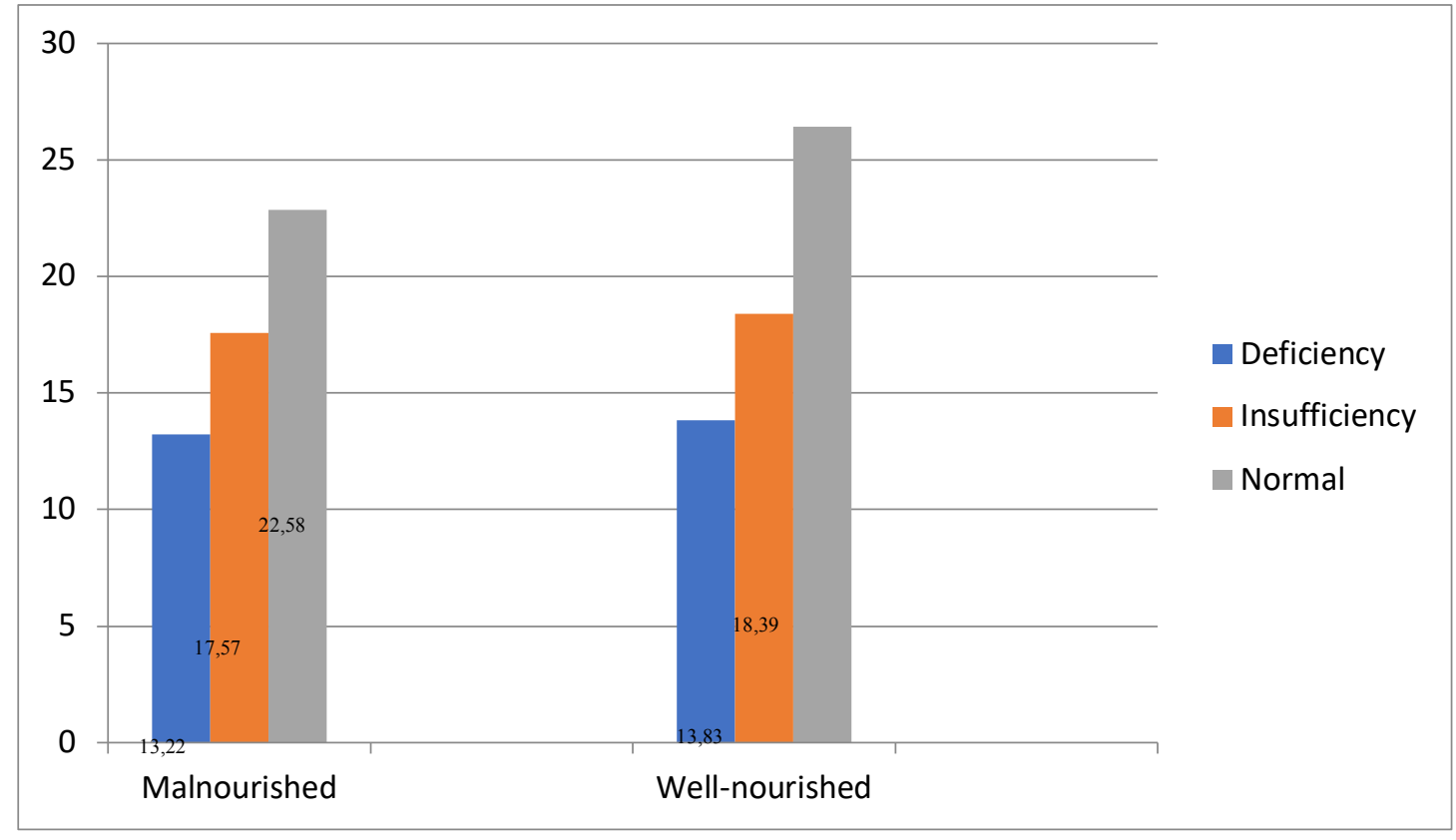

\subsection{Characteristics based on Serum Vitamin D Levels}

Of the 60 people included, based on serum vitamin D levels, the study characteristic is divided into three categories, i.c normal, insufficiency, and deficiency. Based on gender, there were no significant differences in these three categories $(\mathrm{p}=0.09)$, where there were more males $(73 \%)$ in the normal category and more females $(66.7 \%)$ in the insufficiency and deficiency categories.

In the study characteristics, the length of sun exposure is found to had a significant difference in three categories of serum vitamin $\mathrm{D}(\mathrm{p}=0.012)$. This is showed in Table 2 . In this study, the exposure to sunlight has a significant difference in the three categories of serum vitamin $\mathrm{D}$ with a $\mathrm{p}$-value $=0.012$. This characteristic based on serum vitamin D levels can be seen in Table 2 below.

Table 2. Characteristic based serum vitamin D level $(n=60)$

\begin{tabular}{|c|c|c|c|c|}
\hline Characteristic & Defiency & Insufficiency & Normal & p-value \\
\hline
\end{tabular}


$>$ Man

$>$ Woman

Education

$>$ No school

$>$ Elementary

> Middle School

High School

Length of Sun Exposure

$><15$ minutes

$>15$ minutes

Diagnose

Cardiovascular disorder

$>$ Post Trauma

Respiratory disorders

$>$ Fever

$>$ Gastroenteritis

$>$ Surgery cases

> Neurological disorders

$>$ Urinary tract disorders

${ }^{a}$ Chi-Square $\begin{array}{lll}6 & 10 & 16\end{array}$

$\begin{array}{lll}7 & 16 & 5\end{array}$

\subsection{Association Children's Nutritional Status with Serum Vitamin D Level.}

Serum vitamin D levels are influenced by the nutritional status of children. In Table 3, children with wellnourished have normal levels of vitamin D (50\%) and a few of them are malnourished children $(20 \%)$. In insufficiency levels of vitamin D, 40\% of them are well-nourished and $46.7 \%$ are malnourished. Children with well-nourished (10\%) and malnourished (33.3\%) are found in deficiency level of vitamin D. Using the Chi-Square Test, the relationship between nutritional status has a $\mathrm{p}$-value $<0.05$ which is considered as significant meaning in this study.

Table 3. Association nutritional status with vitamin D serum level

\begin{tabular}{lllrl}
\hline Nutritional Status & \multicolumn{2}{c}{ Vitamin D Serum Level } & p-value \\
\cline { 2 - 5 } & Deficiency & Insufficiency & Normal & \\
\hline Malnourished & $10(33,3 \%)$ & $14(46,7 \%)$ & $6(20 \%)$ & $\mathbf{0 , 0 2}^{\boldsymbol{a}}$ \\
Well-nourished & $3(10 \%)$ & $12(40 \%)$ & $15(50 \%)$ & \\
\hline
\end{tabular}

${ }^{a}$ Chi-Square

From 60 research subjects, it is showed that 24 children with malnourishment had abnormal serum vitamin D levels (insufficiency and deficiency). Based on the Chi-Square test, there is a significant correlation in this study, denoted by the RP (Prevalence Ratio) $(1,6)$. It means that research subjects with malnourished will have a 1.6 times greater risk of getting serum vitamin D levels below normal, with a $95 \%$ confidence interval. The data are shown in Table 4.

Tabel 4. Prevalence ratio vitamin D level based on nutritional status

\begin{tabular}{lllll}
\hline & \multicolumn{2}{l}{ Vitamin D level } & \multirow{2}{*}{ RP } & $(95 \% \mathrm{CI})$ \\
\cline { 2 - 4 } Hypovitaminosis & Normal & & $(1.6$ & $(1.072-2.387)$ \\
Malnourished & 24 & 6 & 1 & $(0,180-0,890)$ \\
Well-nourished & 15 & 15 & 1 & \\
\hline
\end{tabular}

\section{Discussion}

In this study, there is a significant relationship between nutritional status and the level of vitamin $D$, with $p=0.02$ and prevalence ratio $(P R)=1.6$. These results indicate that the nutritional status affects the level of vitamin $D$, where the level of vitamin $\mathrm{D}$ in poor nutrition is found lower than in children with good nutrition.

The same results are also obtained in Metha's study that showed the prevalence of vitamin D deficiency in malnourished children was $32 \%{ }^{7}$ A similar finding was also obtained in the Ejaz study in Pakistan where the 
prevalence of vitamin D deficiency was $33.6 \%$ in malnourished children. This high prevalence is caused by the possibility of impaired absorption due to enteric dysfunction or disease processes in malnourished children. It can be exacerbated by the presence of complications such as vomiting associated with infection then can worsen the absorption of vitamin D. ${ }^{16}$

Malnourished children have less adipose tissue than well-nourished children. Adipose tissue acts as a storage site for $25(\mathrm{OH}) \mathrm{D}$, a prohormone produced by the hydroxylation of vitamin $\mathrm{D}_{3}$ by the enzyme cholecalciferol 25-hydroxylase. Vitamin D is one of the important water-insoluble metabolites where the vitamin $\mathrm{D}$ receptor (VDR) in adipose tissue plays a role in the regulation of fat metabolisms such as lipogenesis, lipolysis, adipogenesis, and adipocyte transcription. Thus, providing fat-soluble vitamins such as vitamin $\mathrm{D}$ is thought to play a role in weight gain in malnourished children. ${ }^{17,18}$ In addition, 1,25-dihydroxy vitamin-D, the active form of vitamin D, can induce and induce apoptosis in adipocytes. ${ }^{19}$ Some literature also suggests that lower parathyroid hormone levels can lead to weight loss through thermogenesis and sympathetic nervous system lipolysis. ${ }^{20}$

Malnourished children are more susceptible to infection compare to lower vitamin D levels. Vitamin D deficiency is responsible for changes in the immune response leading to an increased risk of infection. Vitamin D has a role in the regulation of the immune system. Almost all immune systems, including T lymphocytes, express vitamin D receptors. Regulation of vitamin D in modulating the immune response through the mechanism of the presence of VDR on macrophages, monocytes, activated T and B lymphocytes and expressing the enzyme CYP27B1 that can produce 1,25(OH)D. Furthermore, 1,25(OH)D induces decreased expression of costimulatory molecules CD40, CD80, CD86, and IL-12 while simultaneously increasing IL-10 production, promoting dendritic cells to apoptosis and inhibiting $\mathrm{T}$ cell activation. ${ }^{21}$

In this study, there is a significant relationship between the length of exposure to nutrition and vitamin D levels in children with the stratified Chi-Square test, $p=0.008$. In the study, the duration of exposure to sunlight was less than 15 minutes (60\%) and more than 15 minutes (40\%). Vitamin D deficiency is found to be more in children with less nutrition with less than 15 minutes of exposure to vitamin D compared to those with vitamin D exposure more than 15 minutes. This study is in line with Imawari's research that malnourished children are generally less active like normal children, so the opportunity to be exposed to sunlight is less, resulting in low vitamin D levels. ${ }^{13}$

Provitamin D or 7-dehydrocholesterol is dispensed in all layers of the epidermis and dermis, the highest concentrations in the stratum spinosum and stratum basal. Sun exposure to the skin causes the photolytic conversion of 7-dehydrocholesterol to pre-vitamin D3. Provitamin D3 is transformed into vitamin D3 through a thermally induced isomerization process. This endogenous synthesis process in the skin produces vitamin D3 (cholecalciferol), then transported to the liver by vitamin D binding protein (DBP). Once in the liver, vitamin D is converted by the enzyme 25 -hydroxylase to 25 -hydroxy vitamin $\mathrm{D}$ [25(OH)D]. in the kidney into the active form of 1,25-dihydroxy vitamin D [1,25(OH)2D. ${ }^{22}$

Adequate sun exposure does not consider only time, duration, and frequency but also looking at the use of clothing and body protection. Indonesian skin, which is mostly classified as type III and IV, is usually less sensitive to sunlight because it has an intrinsic protection time of 45 minutes. ${ }^{12}$ The area of the body exposed to sunlight has an important role in the synthesis of vitamin D. The wider the skin is exposed, the less solar energy is needed, on the other hand, the lower the area exposed means the lower the risk. Based on research by Miyauchi, it was found that the time required to produce vitamin D as much as $10 \mathrm{~g}$ (400 IU) in the skin with Fitzpatrick type III with an area of skin exposure of $600 \mathrm{~cm} 2$, is $1 / 3$ of the time to reach the Minimum Erythemal Dose (MED). These findings can be used as a reference to determine how long to bask in the sun to get the optimal dose of UVB for vitamin D production and minimize adverse side effects such as skin redness or sunburn. ${ }^{22}$

\section{Conclusion}

In this study, it can be concluded that there is a relationship between the nutritional status of children and serum vitamin D levels. Serum vitamin D levels in malnourished children are lower than in children with good nutrition. This study also showed that there is a significant difference between serum vitamin D levels and duration of sun exposure.

Some examples of how your references should be listed are given at the end of this template in the 'References' section, which will allow you to assemble your reference list according to the correct format and font size.

\section{References}

1. Bagan Tatalaksana Anak Gizi Buku. Kementerian Kesehatan Republik Indonesia, Direktorat Jenderal Bina Gizi Dan Kesehatan Ibu Dan Anak, Direktorat Bina Gizi. Cetakan ke-6. Jakarta; 2011

2. Pusat Data dan Informasi Kementerian Kesehatan Republik Indonesia. Situasi Gizi di Indonesia. Jakarta; 2016

3. Hollis BW. Circulating 25-hydroxyvitamin D levels indicative of vitamin D sufficiency: Implications for establishing a new effective dietary intake recommendation for vitamin D. J Nut. 2005:317-22 
4. Sidiartha GL. Dalam: Sjarif DR, Lestari ED, Mexitalia M, Nasar SS, penyunting. Buku ajar nutrisi pediatrik dan penyakit metabolik. Edisi ke-1. Jakarta: Badan penerbit IDAI; 2011. h.182-9

5. Badan Penelitian dan Pengembangan Kesehatan. 2013. Laporan Hasil Riset Kesehatan Dasar Nasional. Jakarta: Depkes; 2013

6. Agarwal A, Gupta SK, Sukumar R. Hyperthyroidism and Malnutrition with Severe Vitamin D deficiency. World J of Surg. 2009;Vol 33:2303-913

7. Metha S. Vitamin D Levels Among Children with Severe Acute Malnutrition. World J of Pharm Research. 2017;Vol6(5):781-5

8. Saleem J, Zakar R, Zakar MZ, Belay M, Rowe M, Timns PM, et al. High-dose vitamin $\mathrm{D}_{3}$ in the treatment of severe acute malnutrition: a multicenter double-blind randomized controlled trial. Am J Clin Nutr. 2018;107:725-33

9. Maurya M, Sharma P, Srivastava A., Rai R, Singh D.K. Effect of Vitamin D supplementation in children with severe acute malnutrition in a nutritional rehabilitation centre: a randomized contolled trial. Pediatric Review: Int J Pediatr Rerch. 2018:Vol 5(5); 278-83

10. Kennel KA, Drake MT, Hurley DL. Vitamin D Deficiency in Adults : When to test and how to treat. Mayo Clin Proc. 2010;85:752-57

11. Laing CJ, Fraser DR. Changes with malnutrition in concentration of plasma vitamin D binding protein in growing rats. Br $\mathrm{J}$ Nutr.2002;88(2):133-9

12. Nair R, Maseeh A. sVitamin D: The "sunshine" vitamin. J Pharmacol Pharmacother. 2012;3:118-26

13. Holick MF. Vitamin D deficiency. New Engl J Med. 2007;357: 266-81

14. Walker VP, Modlin RL. The vitamin D connection to pediatric infections and immune function. Pediatr Res. 2009;65:106-113

15. Walli NZ, Munubhi EK, Aboud S. Vitamin D Levels in Malnourished Children under 5 Years in a Tertiary Care Center at Muhimbili National Hospital, Dar es Salaam, Tanzania-A Cross-sectional Study. J Trop Pediatr. 2016;10:1-7

16. Ejaz MS, Latif N. Stunting and micronutrient deficiencies in malnourished children. J Pak Med Assoc 2010; 60: 543-7

17. Leblanc, E. S., Rizzo, J. H., Pedula, K. L., Ensrud, K. E., Cauley, J., Hochberg, M., \& Hillier, T. A. (2012). Associations between 25hydroxyvitamin D and weight gain in elderly women. Journal of Women's Health, 21(10), 1066-1073.

18. Jones, K. D. J., Hachmeister, C. U., Khasira, M., Cox, L., Schoenmakers, I., Munyi, C.,Berkley, J. A.Vitamin D deficiency causes rickets in an urban informal settlement in Kenya and is associated with malnutrition. 2018. Maternal and Child Nutrition, 14(1), 1-8.

19. Khosravi, Z,S., Kafeshani, M., Tavasoli, P., Zadeh, A,H., Entezari, M,H. (2018). Effect of Vitamin D supplementation on weight loss, glycemic indices, and lipid profile in obese and overweight women: A clinical trial study. Int. J.Prev. Med. 9:63

20. Zhu, W., Cai, D., Wang, Y., Lin, N., Hu,Q., Qi, Y. Amarasekara, S.(2013). Calcium plus vitamin D3. Supplementation facilitated Fat loss in overweight and obese college students with very-low calcium consumption: a randomized controlled trial. Nutrition Journal, $12(1), 1-8$.

21. Darmatasia W. Peran Vitamin D Dalam Regulasi Sistem Imunitas Melalui Sel Dendritik. Jurnal Ilmiah Kesehatan Median Husada.2012 1(1).55-6

22. Miyauchi M, Nakajima H. Determining an effective UV radiation exposure time for vitamin D synthesis in the skin without risk to health: simplified estimations from UV observations. Photochem Photobiol 2016;92:863-9. 